\section{Viruses Associated with Cucurbit Production in Southern Illinois}

\author{
S. Alan Walters ${ }^{1}$ \\ Department of Plant, Soil and General Agriculture, Southern Illinois University, \\ Carbondale, IL 62901-4415
}

Jeffrey D. Kindhart ${ }^{2}$

Department of Natural Resources and Environmental Sciences, University of Illinois, Dixon Springs Agricultural Center, Simpson, IL 62985

\section{Houston A. Hobbs ${ }^{3}$ and Darin M. Eastburn ${ }^{4}$ \\ Department of Crop Sciences, University of Illinois, Urbana, IL 61801}

Additional index words. cucumber mosaic virus, Cucurbitaceae, papaya ringspot virus, squash mosaic virus, watermelon mosaic virus, zucchini yellow mosaic virus

\begin{abstract}
Viruses are a serious threat to cucurbit production in southern Illinois. The most prevalent viruses infecting cucurbit crops in the region were determined during the 1998, 1999, and 2000 growing seasons to enable growers to make better decisions on viral disease management. Watermelon mosaic virus (WMV) was the most prevalent virus as it was found in $\mathbf{2 8 4 \%}$ of samples over the three years. Cucumber mosaic virus (CMV), papaya ringspot virus (PRSV), squash mosaic virus (SqMV), and zucchini yellow mosaic virus (ZYMV) were detected in $\approx 8 \%, 6 \%, 9 \%$, and $1 \%$ of samples, respectively, over the 3 -year period. WMV was generally the only virus isolated from samples collected before mid-September. Other viruses, including CMV, PRSV, SqMV, and ZYMV, were generally first detected after mid-September and were usually found as mixed infections with WMV.
\end{abstract}

Viruses are a major hinderance to cucurbit production in southern Illinois, with symptoms starting to appear in early June and extending into the fall growing season. Viral infections often render both yellow and zucchini types of summer squash (Cucurbita pepo L.), as well as pickling and slicing types of cucumbers (Cucumis sativus L.) unmarketable due to the symptoms produced on fruit. Viruses are a serious problem for commercial cucurbit producers in southern Illinois, as many growers have realized complete losses. The viruses that typically cause problems on cucurbits in the United States include cucumber mosaic virus (CMV), papaya ringspot virus (PRSV), squash mosaic virus (SqMV), watermelon mosaic virus (WMV), and zucchini yellow mosaic virus (ZYMV) (Robinson and Decker-Walters, 1997; Zitter et al., 1996). Viruses infecting cucurbits in various states have been determined (Davis and Mizuki, 1987; Nameth et al., 1986; Provvidenti et al., 1984; Sammons et al., 1989; Ullman et al., 1991; Webb, 1971), but there is no available information to the most important viruses infecting cucurbits in southern Illinois. The proper identification of the most prevalent cucurbit viruses in the region

\footnotetext{
Received for publication 11 Dec. 2001. Accepted for publication 24 June 2002. The use of trade names does not imply endorsement by Southern Illinois University or the Univ. of Illinois of the products named or criticism of similar ones not named. The research presented in this publication was funded in part by a grant obtained from the Illinois Council on Food and Agricultural Research.

${ }^{1}$ Assistant Professor.

${ }^{2}$ Senior Research Specialist-Horticulture.

${ }^{3}$ Research Associate.

${ }^{4}$ Associate Professor.
}

would enable growers to make better decisions on viral disease management. The primary objective of this study was to determine the most prevalent viruses found infecting commercially grown cucurbits in southern Illinois during the 1998, 1999, and 2000 growing seasons.

\section{Materials and Methods}

Leaf samples of slicing and pickling cucumber, muskmelon (Cucumis melo L.), jack-o-lantern pumpkin (Cucurbita pepo L.), yellow and zucchini squash, and watermelon [Citrullus lanatus (Thunb.) Matsum. \& Nakai] exhibiting symptoms of viral infection were collected from commercial fields in southern Illinois during the 1998, 1999, and 2000 growing seasons to determine the cucurbit viruses present. Cucurbit samples were collected from Gallatin, Jackson, Pulaski, and Union counties during all three growing seasons; samples were also collected from Johnson (1998, 1999), Madison (2000), Massac (1999), Pope (1998), St. Claire (1999, 2000), Williamson (1999, 2000), and White (2000) counties. Most of the counties in southern Illinois that have commercial cucurbit production were included.

Foliage samples were placed in plastic storage bags and were frozen within $2 \mathrm{~h}$ of collection. Samples were maintained in plastic bags in a $-20{ }^{\circ} \mathrm{C}$ freezer until they were tested for the viruses present, which was usually within a month. A total of 28, 36, and 91 samples were collected for the 1998, 1999, and 2000 growing seasons, respectively. About 10 fresh samples (not frozen) symptomatic of virus infection were collected at various locations during each year to obtain fresh plant material to test Koch's postulate. Viruses were extracted from fresh samples for inoculation of 'Grey Zucchini' plants. Foliage of fresh samples were ground using mortars and pestles in cold $0.025 \mathrm{M} \mathrm{po-}$ tassium phosphate buffer, $\mathrm{pH} 7.1$, with 0.01 M sodium sulfite. Inoculum was spread with pestles on carborundum-dusted cotyledons and leaves of 'Grey Zucchini' squash seedlings, and the plants were rinsed with water afterward. Plants were maintained for 3 weeks in a growth chamber to allow symptom development.

Cucurbit samples were tested for the presence of five viruses: CMV, PRSV, SqMV, WMV, and ZYMV, utilizing alkaline phosphatase enzyme-linked immunosorbent assay (ELISA) kits (Agdia Pathoscreen kits, Agdia, Elkhart, Ind.). Samples were considered positive if absorbance readings equaled or exceeded $3 \times$ the absorbance of negative controls (healthy cucurbit leaves).

\section{Results and Discussion}

Watermelon mosaic virus was the most prevalent cucurbit virus in southern Illinois for all three years; it was found in $93 \%, 83 \%$, and $75 \%$ of the samples collected during the 1998 , 1999 , and 2000 growing seasons, respectively (Fig. 1). Cucumber mosaic virus was found all three years in a low percentage of the samples (4\%,11\%, and $8 \%$ for the 1998, 1999, and 2000 growing seasons, respectively). PRSV and ZYMV were each detected in $4 \%$ of the samples collected during the 1998 growing season, and neither were found during 1999; only PRSV was found during 2000, being detected in $14 \%$ of samples. SqMV was not detected in 1998 , but was detected in $19 \%$ and $8 \%$ of the samples in 1999 and 2000, respectively. SqMV can be seed-transmitted (Thomas, 1973; Zitter et al., 1999), and its increased presence during the 1999 and 2000 growing seasons may be attributed to seed transmission.

In all cases for the fresh samples that were collected each year, symptoms of virus infection were produced on the 'Grey Zucchini' plants inoculated and the virus identified was identical to the original virus isolated from field foliage samples.

Generally, WMV was the only virus detected in samples collected early in the production season (June to mid-September); CMV was the only other virus that was detected before mid-September and it was found only in a few samples. Other viruses besides WMV were generally first detected after mid-September and were usually found as mixed infections with WMV.About $15 \%$ of the samples collected over the 3-year period had mixed infections of two or more viruses (data not presented). In most cases, the mixed infections occurred after mid-September and were WMV with one or more other viruses. Of the mixed infections, WMV was found with CMV (13\%), PRSV (42\%), SqMV (21\%), ZYMV (4\%), CMV and PRSV (4\%), CMV, PRSV and SqMV (4\%), and PRSV and SqMV (4\%); only two mixed infections did not contain WMV and both were CMV and SqMV (8\%).

The cucurbit species sampled were infected similarly by most of the viruses identified (except SqMV), as there was generally no specific- 


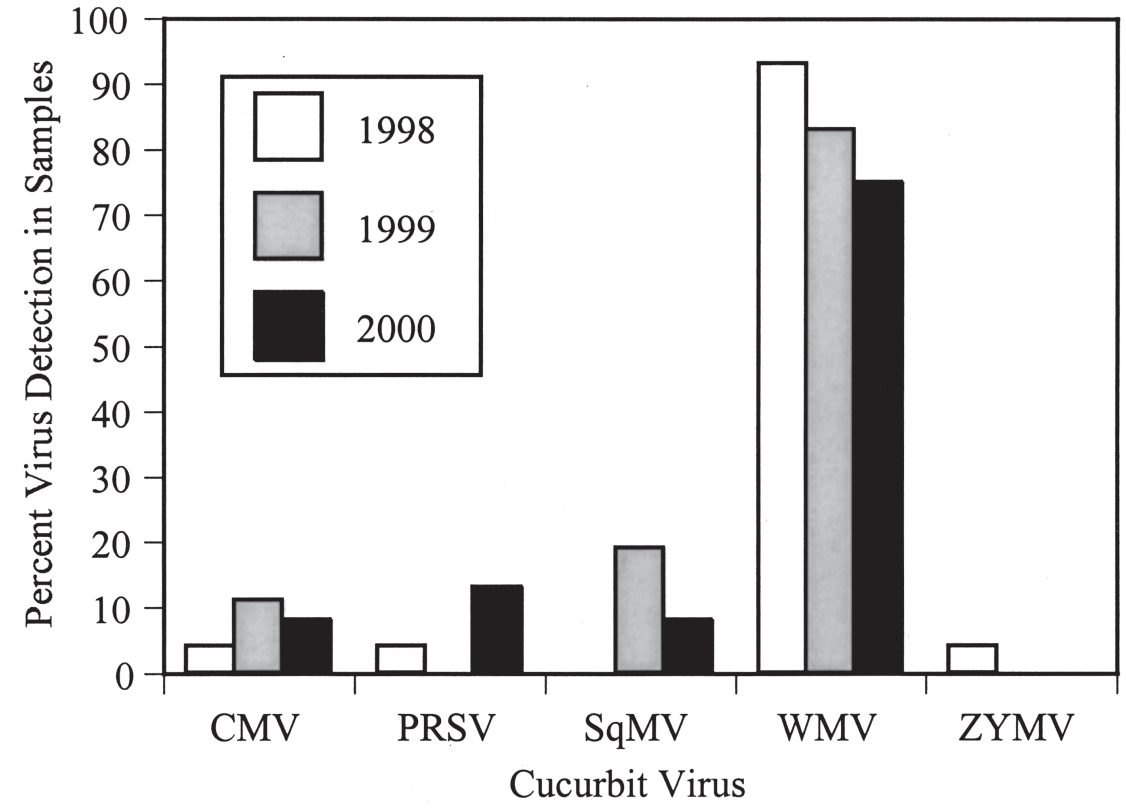

Fig. 1. Percentages of cucurbit samples infected with each of five viruses in southern Illinois during the 1998, 1999, and 2000 growing seasons.

ity of a particular virus to infect one cucurbit compared to another. SqMV was found only infecting Cucurbita pepo, including 'Howden' pumpkin (1999 and 2000), 'Independence II' zucchini squash (1999 and 2000), 'Liberator III' yellow squash (1999 and 2000), and 'Cougar' yellow squash (1999 only).
WMV was the most prevalent virus infecting cucurbits in southern Illinois, as it was found in $\approx 84 \%$ of foliage samples collected over the 3-year period. Cucurbit field losses due to viruses in southern Illinois could have been reduced if cultivars were grown that had tolerance or resistance to WMV. Over the three growing seasons, WMV was found infecting cucumber, muskmelon, pumpkin, squash, and watermelon.

\section{Literature Cited}

Davis, R.F. and M.K. Mizuki. 1987. Detection of cucurbit viruses in New Jersey. Plant Dis. 71(1):40-44.

Nameth, S.T., J.A. Dodds, A.O. Paulus, and F.F. Laemmlen. 1986. Cucurbit viruses of California: An ever-changing problem. Plant Dis. 70(1):8-11.

Provvidenti, R., D. Gonsalves, and H.S. Humaydan. 1984. Occurrence of zucchini yellow mosaic virus in cucurbits for Connecticut, New York, Florida, and California. Plant Dis. 68(5): 443-446.

Robinson, R.W. and D.S. Decker-Walters. 1997. Cucurbits. CAB Intl., Wallingford, U.K.

Sammons, B., O.W. Barnett, R.F. Davis, and M.K. Mizuki. 1989. A survey of viruses infecting yellow summer squash in South Carolina. Plant Dis. 73(5):401-404.

Thomas, W. 1973. Seed-transmitted squash mosaic virus. N.Z. J. Agr. Res. 16:561-567.

Ullman, D.E., J.J. Cho, and T.L. German. 1991. Occurrence and distribution of cucurbit viruses in the Hawaiian islands. Plant Dis. 75(4): 367-370.

Webb, R.E. 1971. Watermelon mosaic viruses 1 and 2 in squash on the Atlantic seaboard. Plant Dis. Rptr. 55(2):132-135.

Zitter, T.A., D.L. Hopkins, and C.E. Thomas. 1996. Compendium of cucurbit diseases. APS Press, St. Paul, Minn. 